Pregledni članak

Bojana O. Arsenijević, Ph.D. Student

University of Niš

Faculty of Law Niš

bojana.arsa@yahoo.com

\title{
FORMS OF WILLS IN CONTEMPORARY RUSSIAN LAW, WITH PARTICULAR REFERENCE TO SERBIAN LAW
}

\begin{abstract}
In the paper the author analyses the forms of wills in Russian law and the conditions for their legal validation. The domination of public form of a will is noticeable. Thus, the regulated forms of wills are the notarial will, the wills qualified as wills attested by a notary and the secret will. Since the Russian Federation has ratified the Convention providing a Uniform law on the Form of an International Will, Russian law regulates the international will as well. Bearing in mind the exceptional situations the citizen could find himself (herself), Russian legislator has regulated the handwritten will before witnesses, which is the only private form of a will in Russian law. The specific legal norms regulate testimonial dispositions of the monetary effectives at the banks or other credit organizations. The analysis of legal norms of Russian law provides the possibility to light on the similarities and distinctions between them and the comparative succession regulations of other European countries, and primary with the Serbian succession law.
\end{abstract}

Keywords: Russian law, Serbian law, form of a will, the conditions for legal validation.

\section{INTRODUCTION}

The freedom of testamentary disposition is one of the essential expressions of the autonomy of will, with a post mortem effect. Since the fulfilment of performed testamentary dispositions depends on the validity of a form of will they were expressed in, the regulation of forms of wills in Russian law represents a topic worth of special attention, particularly bearing in mind that the Russian Federation is one of larger centres of business migration of citizens of the Republic of Serbia. 
Unlike the Civil Code of the Union of Soviet Socialist Republics 1964, which regulated a will rather as an exception than as a rule, the norms of the Civil Code of the Russian Federation 2001 endeavour to enable the broadest possible circle of people creating their last will. ${ }^{1}$ Two regular forms of wills are regulated: notarial will and closed will. ${ }^{2}$ Taking care of the circumstances where a public notary is not available to the testator, the authorisations of specific persons to perform the attestation of a will are prescribed by the law, whereby such an attestation is equalised with a notarial attestation of a will. A handwritten will before witnesses, drawn up under special circumstances, is also standardised as an exceptional form of a will. In addition to these four forms of wills, special regulations for testamentary dispositions of pecuniary funds on accounts in banks and other credit organisations are also regulated. ${ }^{3}$

In the seventies of the last century, an idea on the creation of a form of international last will and testament crystallised, as a response to the observed danger that any last will and testament drawn up in one country would not be valid in another country, due to the discrepancies in national legal regulations and forms of last wills and testaments. The UNIDROIT Convention providing a Uniform Law on the Form of an International Will 1973 creates a new form of will, an identical one for all the states signatories of the Convention, ${ }^{4}$ including Russia. Therefore, it is also possible to realise testamentary disposition in Russian law in a form of international will.

The Inheritance Act of the Republic of Serbia stipulates the following regular forms of wills: handwritten will, written will before witnesses, judicial will, consular will, international will and notarial will. As extraordinary forms of wills, wills drawn up abroad a vessel and soldiers' wills are regulated. Taking into account special circumstances, Serbian legislator also standardised oral will as an exceptional form of will. ${ }^{5}$

${ }^{1}$ See: Юлия Борисовна Лотарева, „Свобода завещания и случаи ее ограничения“, Вестник Российского университета дружбы народов, Серия: Юридические науки, 4/2010, 74.

${ }^{2}$ On the classification of forms of last wills and testaments into public and private, regular, extraordinary and exceptional wills, as well as written and oral ones, see: Nataša Stojanović, Nasledno pravo, Niš, 2011, 207-208. On the characteristics of extraordinary forms of last wills and testaments, see: Jelena Vidić, Vanredni oblici zaveštanja u pravu Srbije i ostalim savremenim pravima Evrope, Zbornik radova Pravnog fakulteta u Novom Sadu, 4/2017, 1542-1543.

${ }^{3}$ See art. 1124-1129 of the Civil Code of the Russian Federation (Гражданский кодекс Российской Федерации 1994, with the latest amendments 2018, hereinafter: The RFCC and The RF Civil Code, source: https://www.zakonrf.info/gk, 05 March 2019).

${ }^{4}$ The Convention was passed under the auspices of the International Institute for the Unification of Private (UNIDROIT) 1973, Washingtone, USA. So far, the Convention has been ratified by 21 countries from all the continents. The USSR accessed the Convention in 1974, and following the dissolution of the common country, the Russian Federation notified the depository government of the USA on the continuation of the application of the Convention. Interestingly, the official versions of the Convention were written in French, English, Spanish and Russian. Source: http://www.unidroit.org/instruments/succession, 10 April 2019.

${ }^{5}$ See art. 84-111a of the Inheritance Act - IA, (Zakon o nasleđivanju, Službeni glasnik RS, br. 46/95, 101/2003 - odluka USRS i 6/2015). 
Further on in this paper, we will analyse the mentioned forms of will in Russian law and the conditions for their legal validity, and also review the similarities and differences between the systems of forms of wills in Russian and Serbian laws.

\section{NOTARIAL WILL}

Contemporary Russian law regulates notarial will, ${ }^{6}$ as a public, regular and written form of will. It is a general rule that a will must be created in writing and attested by a notary. ${ }^{7}$ In places where there is no a public notary, the attestation of a will must be performed by an official of executive authorities, and abroad - an official of a consular institution of the Russian Federation. ${ }^{8}$

In this way, the Russian legislator endeavoured to protect the testator against any influence of fraud, force or threat by stakeholders, through the participation of a notary in the process of drawing up his/her will. Thereby, it is assumed that the notary will take care of the clarity of expressing the testator's last will and there will be no problems in understanding the provisions of the will after its proclamation. ${ }^{9}$ Also, the notary ensures that the expressed will of the testator may exercise its legal effect, by warning the testator to legal regulations related to a valid creation of a will and to the imperative norms restricting the freedom of testamentary dispositions.

\subsection{The manner of drawing up a notarial will}

First, the notary establishes the identity of the testator on the basis of his/her personal document. ${ }^{10}{ }^{11}$ At the same time, the notary controls whether that person

${ }^{6}$ The formulation of the Russian legislator is „notarialbno udostoverennoe zaveщаnie”, meaning ,a will attested by a notary”. However, the use of ,notarial will” syntagm to designate this form of will detracts nothing from the meaning given by the Russian legislator, and it is a common one in domestic legal literature, thus also more understandable. Additionally, considering the two manners of drawing up this form of will, saying on records to a notary and passing the writ to the notary, we can speak about a notarial attestation in terms of notarial activities regulations in Serbian law, stricto sensu in the latter case only. When a notary takes the statement of the last will of a testator on the records, then he/she also undertakes additional activities, which are not included by the term attestation.

${ }^{7}$ See art. 1124, para 1 of the RFCC.

${ }^{8}$ See art. 1125, para 7 of the RFCC; Институт Государства и права Российской Академии Наук, Комментарий к Гражданскому Кодексу Российской Федерации, Части Третьей, Москва 2004, 29; Институт Законодательства и Сравнительного правоведения при правительстве Российской Федерации, Комментарий к Гражданскому Кодексу Российской Федерации, Части Третьей (Постатейный), Второе Издание, Москва 2007, 43-44.

${ }^{9}$ See: Рашад Афатович Курбанов et al, Наследственное право, Москва 2018, 77.

${ }^{10}$ See: Институт Государства и права Российской Академии Наук, 29.

${ }^{11}$ For Russian citizens, a personal document for establishing identity is their passport, and for foreign citizens - a passport or other document, stipulated by federal law or recognised by 
is at the age required for drawing up a will. ${ }^{12}$ Presumably, the person requesting the attestation of will is capable of judgement. In case of doubt, the notary may refuse drawing up the will. ${ }^{13}$

The manner of drawing up a notarial will is regulated in a dual way. The testator may state his/her last will orally on records before a notary or may pass a writ to the notary, which contains his/her own last will. ${ }^{14}$ Thus, the written redaction of the wording a will may be done by a notary or the testator themself. The will, in the former case, compulsory contains a note ,the wording of the will is written by the notary based on my words" and ,the wording of the will is written by myself personally" in the latter one..$^{15}$

When the notary receives the testator's will on records, he/she does not have to and need not to formulate the wording of the will literally to the testator's statement, yet he should endeavour to use precise and legal terms, paying attention not to deviate from the contentual meaning of the testator's last will. Thereby, the notary is obliged to state in the will that he/she have explained to the testator the essence of a compulsory share institute and the restriction that it represents for his/her dispositions. ${ }^{16}$ The testator should directly state his/her last will in the manner in which the notary may conclude that the testator's will is free and serious. In the situations where it is required so, the testator may state his/her will with the assistance of an interpreter or a translator, unless the notary can speak the language that the testator uses. The testator should read out the written will by themself, and if it is not possible, the notary will read the text for him/her, with the participation of an interpreter eventually. A relevant annotation will be made regarding this fact in the will itself, whereby stating the reasons why the testator could not read the will by themself. ${ }^{17}$

international treaty as a document confirming the identity of the foreign citizen. For a person without citizenship it may be a document issued by another state, and which is recognised by an international treaty, a temporary residence permit, residence permit, or any other document stipulated by federal law or recognised by an international treaty confirming the identity of the person without citizenship. See: Михаил Сергеевич Абраменков, Петр Валерьевич Чугунов, Наследственное право, Москва 2019, 197-198.

${ }^{12}$ In Russian law, testamentary disposition is acquired after reaching the age of majority, with the attainment of the age of eighteen years. A person that has not attained the age of eighteen years may draw up his/her will if he/she acquired full dispositive capacity based on emancipation or concluding marriage after they have attained the age of sixteen years with the approval of a court-of-law. See art. 1118 in conjunction with art. 21 and 27 of the RFCC.

${ }^{13}$ It is emphasised in legal literature that actually a notary has no possibility to refuse attestation of will, even when doubting the testamentary capability of persons. Namely, a notary is not entitled to request any medical check-up of the judicial decision on dispositive capacity (consequently, a testamentary one) of a person and cannot refuse the attestation of a will based on his/her own assumption. See: M. S. Abramenkov, P. V. Čugunov, 199.

${ }^{14}$ See art. 1125 , para 1 of the RFCC.

${ }^{15}$ See: M. S. Abramenkov, P. V. Čugunov, 199.

${ }^{16}$ See art. 1125, para 6 of the RFCC.

${ }^{17}$ See art. 1125, para 2 of the RFCC. 
When the testator passes the writ to the notary as his/her own will, it is prescribed that the writ must be written by the testator himself (herself) with an imperative norm. However, the legislator explicitly emphasised that it is irrelevant whether the writ was handwritten or technical facilities were used (computer, typewriter, etc.). ${ }^{18}$ The notary is obliged to read out the received will and to explain the testator the legal meaning of the committed testamentary dispositions.

The legislator did not stipulate, as a precondition for the validity of a notarial will, the attendance of a witness when a will is drawn up, however a witness can be in attendance it the testator wishes so. ${ }^{19} \mathrm{~A}$ testamentary witness cannot be any person, although the legal limitations are minimal. ${ }^{20}$ So, a witness cannot be a person without full dispositive capacity, and an illiterate person, or a person with such physical disabilities that do not allow him/her to understand the essence of the event of drawing up a will in full, as well as a person without a sufficient degree of command of the language in which the will is written (absolute prohibitions). Also, a notary or other authorised person who attests the will, a person being a beneficiary of the will or for whom the will is revoked, as well as the spouse, children and parents of that person cannot act in the capacity of a witness (relative prohibition). ${ }^{21}$ The same limitations are also valid for the person who signs on the testator's behalf. Not observing these statutory limitations is the reason for the annulment of the will. ${ }^{22}$ These general norms, in regard to the characteristics of a testamentary witness, are valid for every form of a will.

Contrary to the series of rules used by the Russian legislator to regulate a notarial will, the Serbian legislator committed one norm to this issue: A notarial will is drawn up by a notary in a form of a notarial written record. ${ }^{23}$ The very procedure for drawing up a will is regulated with the provisions of the Act on Non-Contentious Proceedings. ${ }^{24}$ In principle, the procedure for drawing up a will does not significantly deviate from the presented rules of the Russian law, except

${ }^{18}$ See art. 1125 , para 1 of the RFCC.

${ }^{19}$ See art. 1125, para 4 of the RFCC. We point out that the Russian legislator uses the noun witness in singular in this legal norm. However, there are no imperative legal obstacles for the attendance of more witnesses when a will is drawn up, it the testator wishes so.

${ }^{20}$ We differentiate two types of limitations, absolute and relative prohibitions. Absolute prohibitions are related to those characteristics of persons, which, according to the legislator's stand, prevent the person from witnessing the act of creation of a will actually and seriously. Relative prohibitions are related to the characteristics or relations of the person appearing as a witness in the procedure of drawing up a concrete will.

${ }^{21}$ See art. 1124, para 2 of RFCC; Институт Законодательства и Сравнительного правоведения при правительстве Российской Федерации, 45-46.

${ }^{22}$ See art. 1124, para 3 of the RFCC.

${ }^{23}$ See art. 111a of the IA.

${ }^{24}$ See: 165-183 of the Act on Non-Contentious Proceedings - AN-CP, (Zakon o vanparničnom postupku, Službeni glasnik SRS, br. 25/82 i 48/88, i Službeni glasnik RS, br. 46/95 - dr. zakon, 18/2005 - dr. zakon, 85/2012, 45/2013 - dr. zakon, j55/2014, 6/2015 i 106/2015 - dr. zakon). 
that a notarial will can only be drawn up by saying it on the records to the notary public in the Republic of Serbia.

\subsection{The attestation of a notarial will}

The testator must sign the will with his/her own hand, as a rule, in the presence of a notary. ${ }^{25}$ If the testator does not know how to sign his/her name or is not able to do it, due to illiteracy, physical disability or grave illness, the possibility that another citizen signs it at his/her request is stipulated. ${ }^{26}$ That person is obliged to sign on behalf of the testator with a notary in attendance, who will state the reasons in the will why the testator could not sign the will by himself (herself) and also the personal particulars of the person who signed on the testator's behalf.

Besides the testator, that is to say the person who signed on behalf of the testator, the will is also signed by all the other persons who, eventually, participated the creation thereof: translator, interpreter and witness. All these persons, including also the person who signed on the testator's behalf, will be warned on their legal duty to observe the secrecy of a will. ${ }^{27}$

Finally, the notary sings his/her will and indicates the place and the date of the attestation of the will. A notarial will is drawn up, signed and attested in two copies, one of which is passed to the testator, and the other one remains with the notary. ${ }^{28}$

It is interesting to point out the Serbian legislator's solution. A testator who cannot sign with his/her own hand, may affix a fingerprint of the index finger on the will. If the testator is incapable of doing that, then, one of the witnesses signs it on behalf of the testator. ${ }^{29}$

\section{CLOSED WILLS}

Since the attendance of witnesses is not compulsory when drawing up a notarial will, no other third person must know about the content of the will, save for the notary. Regulating a closed will, the Russian legislator provides a possibility to

${ }^{25}$ See: Институт Государства и права Российской Академии Наук, 29.

${ }^{26}$ See art. 1125, para 3 of the RFCC.

${ }^{27}$ See art. 1125, para 5 of the RFCC. The legal duty to observe the secrecy of a will refers to the content of the will and the facts of drawing up, amending or revoking the will. The consequence of violating this legal duty is a civil liability for the compensation of moral damages, the liability for which exists irrespective of culpability thereof. Also, it is possible to claim material damages, caused by the violation of the secrecy of a will. See: Институт Государства и права Российской Академии Наук, 27; Ю. Б. Лотарева, 75-76.

${ }^{28}$ See art. 1124, para 4 of the RFCC. The notary may check up whether the will is withdrawn or amended, and establish the original will and the subsequent one(s) among several wills per the place and the date of attestation. See: M. S. Abramenkov, P. V. Čugunov, 197 and 200.

${ }^{29}$ See art. 179 of the AN-CP. 
the testator to keep the testamentary dispositions secret from all persons, including also the notary.

Although being an atypical form of a will for the Balkans legal area, this public, regular and written form of a will is broadly present in European legal systems. Even fourteen European countries regulate secret wills. ${ }^{30}$ The Serbian legislator did not provide for a possibility of testamentary disposition in a form of a secret will.

The basic advantage of such a closed will is the preservation of the secrecy of its contents. However, because of the preserved privacy of testamentary dispositions in such a manner, any eventual defects of the testamentary form and the content of a will, which will only be disclosed on the occasion of the proclamation of the will, may cause invalidity of the will. ${ }^{31}$

The imperative legal norm prescribes that the testator's closed will must be handwritten and signed with his/her own hand. ${ }^{32}$ The strict requirement of its form is justified with the impossibility of a notary to check, on the occasion of accepting a closed will, the conformity of the testator's actual will and the will expressed in that writ, ${ }^{33}$ whereby the assurance on consent is exactly provided with the fact that the will is handwritten. A logical consequence of the stated requirements is a significant and unjustified narrowing down of the circle of people who may express their last will in a form of a closed will. The requirement of hand-writing and signing with one's own hand may represent an insurmountable obstacle for illiterate people or persons with disabilities.

The procedure of passing a handwritten and signed will to a notary is regulated in detail. ${ }^{34}$ First, the testator passes his/her will to the notary, in a sealed envelope, in the presence of two witnesses. Then, the testamentary witnesses sign the envelope in the presence of the testator and the notary. The envelope signed in such a way, in the presence of the testator and the testamentary witnesses, is sealed and put into another envelope by the notary, where he/she enters the information on the testator, on the place and date of accepting thereof, and the personal data of the testamentary witnesses, as well as the annotations provided to the testator. ${ }^{35}$ Figuratively speaking, the will's acceptance procedure takes place according to „babushkas” principle, because, when looking at it in a reverse order, when proclaiming the will, one envelope is opened, in which there is another envelope, in which there is the will. ${ }^{36}$

${ }^{30}$ See: Bojana Arsenijević, Tajno zaveštanje u pojedinim savremenim evropskim pravnim sistemima, Zbornik Pravnog fakulteta u Nišu, 78/2018, 408-409.

${ }^{31}$ On advantages and disadvantages of a closed will, see: Ibid. 416-418.

${ }^{32}$ See art. 1126, para 2 of the RFCC.

${ }^{33}$ See: R. A. Kurbanov et al, 79.

${ }^{34}$ See: Ibid. $78-79$.

${ }^{35}$ See art. 1126, para 3 of the RFCC.

${ }^{36}$ A set of babushkas (Russian: матрёшка, matron - matriarchat) is a Russian wooden toy consisting of dolls which separate at the middle, to reveal a smaller doll inside, which has another doll inside of it, and so on. 
The notary does not attest a closed will, but certifies the fact that the will has been given to him and that the testator is familiar with its legal effects. ${ }^{37}$ The notary is obliged to warn the testator on the requirements of the validity of the form of a closed will and on the consequences of not fulfilling these requirements, as well as the right of the legal heirs to the compulsory share. These annotations are stated on the second envelope by the notary. ${ }^{38}$

Finally, the notary gives to the testator a certificate on the acceptance of his/her closed will. The date of the acceptance of the will by the notary is considered the date of drawing up the closed will, which is stated in the certificate on acceptance. ${ }^{39}$

What is said earlier in relation to a notarial will is also valid about absolute and relative prohibitions in regard to the characteristics of testamentary witnesses. However, we are pointing out one difference in relation to the earlier presented rules - it is not necessary that the testamentary witnesses speak Russian, i.e. the language in which the closed will is written, while bearing in mind that these witnesses need not to be familiar with its content. ${ }^{40}$

Some legal systems regulating a closed will prescribe a conversion of the will form, considering the already highlighted danger of the invalidity of the testator's testamentary dispositions, due to the lack of control of the closed will contents by the notary. ${ }^{41}$ For instance, French and Italian laws provide for that, if the last will does not meet the requirements for a secret will, it will be valid as a holographic will, if the requisites for its validity are fulfilled. ${ }^{42}$ However, the Russian legislator did not accept such a solution, although explicitly requests that the closed will must we handwritten and signed by the testator. The reason for that lies in the fact that a handwritten will before witnesses in Russian law is an exceptional form of will, thus it cannot be a substitute for a closed will as a regular form of a will.

${ }^{37}$ See: M. S. Abramenkov, P. V. Čugunov, 204; Институт Законодательства и Сравнительного правоведения при правительстве Российской Федерации, 47.

${ }^{38}$ See: R. A. Kurbanov et al, 79.

39 See: Ibid.

${ }^{40}$ See art. 1124, para 2 of the RFCC. Институт Государства и права Российской Академии Наук, 28.

${ }^{41}$ Conversion of a form of a will means that a will drawn up in a certain form, but not meeting all the requirements of the form of the intended type, is valid as another type of a will by the legislator's will, if the requirements for the form of that other type are met. It is intended to assure the validity of the testator's testamentary disposition and fulfil his/her last will in this way.

${ }^{42}$ See art. 976, para 2 and art. 979, para 2 of the French Civil Code (Code Civile 1804, with the latest amendments 2019, hereinafter: FCC, source https://www.legifrance.gouv.fr/affichCode. do?cidTexte=LEGITEXT000006070721, 29. July 2019); art. 604, para 1 and art. 607 of The Italian Civil Code (Codice Civile 1942, with the latest amendments 2019, hereinafter: ICC, source https:// www.altalex.com/documents/codici-altalex/2015/01/02/codice-civile, 17 June 2019). French and Italian laws prescribe that the testator may present as a secret will a writ, handwritten or written using technical facilities for writing, as well as a writ written by another person, and signed by the testator confirming its content. 


\section{FORMS OF WILLS QUALIFYING AS WILLS ATTESTED BY A NOTARY}

The regular way for drawing up a will in Russian law is saying on the records to a notary or presenting an opened or closed document to a notary. Acknowledging the life situation in which a person may find themself, in which getting in touch with a notary would imply certain greater efforts or impossibility, the Russian legislator regulated the forms of wills qualified as wills attested by a notary, ${ }^{43}$ as public, extraordinary, and written forms of a will.

\subsection{Regulated forms of wills qualifying as wills attested by a notary}

According to the letter of the law, the following wills qualify as wills attested by a notary: 1) wills of citizens undergoing medical treatment in in-patient institutions, hospitals, other stationary medical institutions or residing in eldercare and skilled nursing facilities attested by the chief physicians, deputy chief physicians in charge of medical work or physicians on duty at these in-patient institutions, hospitals and other stationary medical institutions, and also the chiefs of the hospitals, directors or chief physicians of eldercare and skilled nursing facilities; 2) wills of citizens who stay aboard vessels during their navigation, if such vessels navigate under the State Flag of the Russian Federation, attested by the captains of these vessels; 3) wills of citizens who are in prospecting, Arctic or other similar expeditions, attested by the chiefs of these expeditions; 4) wills of military servicemen in the places of deployment of military units where there are no notaries, also wills of civilians employed by these units, members of their families and members of the families of military servicemen, attested by the commanders of the military units; and 5) wills of citizens staying at penitentiary institutions, attested by the chiefs of the penitentiary institutions. ${ }^{44} 45$

43 The formulation of the Russian legislator is ,zaveщаniя, priravnivaemыe k notarialsno udostoverennыm zaveщаniяm”, meaning „wills qualifying as wills attested by a notary”.

${ }^{44}$ See art. 1127, para 1 of the RFCC.

${ }^{45}$ In legal literature we encounter an opinion that the mentioned list should be supplemented with wills attested by officials of the executive authorities in local self-government units and consular representatives of the Russian Federation. See: R. A. Kurbanov et al, 81. Contrary, see: M. S. Abramenkov, P. V. Čugunov, 201. It is necessary to point out that such an amendment would not be acceptable. Officials of executive authorities in local self-government units and consular representatives of the Russian Federation are entitled to accomplish notarial actions in places where their registered seat is located, in case that there is no notary in these places, and in compliance with art. 1125 of the RFCC they may also attest a will. To the contrary, the authorisations of persons referred to in art. 1127 of the RFCC refer only to the attestation of a testator's will who finds himself (herself) at an exactly specific situation. Whereby, according to art 1127, para 4 of the RFCC, these persons are obliged to do everything, as the testator so wishes, to invite a notary to attest the will, 
It is interesting that the comparative law solutions demonstrate an individualistic approach when regulating extraordinary forms of a will. So, the following extraordinary forms of a will are regulated in French law: wills of soldiers, wills in the conditions of contagious disease, wills made in an island, and a will made during the course of a sea voyage. ${ }^{46}$ Extraordinary, that is to say special wills in Italian law are wills in conditions of contagious disease, general disaster or accident, wills drawn up aboard a vessel, wills drawn up in a plane, and soldiers' wills. ${ }^{47}$ The normed extraordinary forms of wills in Serbian law are wills drawn up aboard a vessel and soldiers' wills. ${ }^{48}$ Contrary to these examples, Russian law regulates a unique, group extraordinary form of a will, comprising five sub-forms of a will.

Regulating wills drawn up aboard a vessel is an expression of extraterritorial expansion of the state sovereignty. This is perhaps the most frequently extraordinary form of a will, considering the previously expressed comparative law solutions on extraordinary forms of a will. There are two material requirements for drawing up a will: that a will may only be drawn up aboard a vessel sailing under the State Flag of the Russian Federation and only during the navigation.

Contrary to the Roman law, where soldiers' will was drawn up by soldiers during a war or mobilisation, ${ }^{49}$ in Russian law drawing up such a will is not conditioned upon the existence of war circumstances, but upon the fact that the person is in a military unit in a place where there is no notary. Whereby, such a will may draw up both a member of military and a person employed with a military unit and the members of families of such persons. ${ }^{50}$

Consideration of the Russian legislator for including specific situations in which the testator finds themself on the occasion of standardising this form of a will, particularly became evident in regulating the will of a person who is in a stationary medical institution or residing in eldercare and skilled nursing facilities. Bearing in mind the testator's health status, this form of a will provides the conditions for drawing up a will, not having to spend time queueing for a notary. This sense for recognising real social needs was also expressed by the Russian legislator when regulating wills for persons staying at penitentiary institutions. The

that is to say an official of executive authority in local self-government units where there is no notary. Thereupon, these legal situations of attesting a will cannot be equalised.

${ }^{46}$ See art. $981-998$ of the FCC.

${ }^{47}$ See art. $601-623$ of the ICC.

${ }^{48}$ See art. $108-109$ of the IA.

${ }^{49}$ It is about an informal will that was drawn up by Roman soldiers in a military encampment or before going to the battle - testamentum im procintu. See: Adolf Berger, Encyclopedic Dictionary of Roman Law, vol. 43, part 2, Philadelphia 1953, 733.

${ }^{50}$ Considering that this will in Russian law may also be drawn up by civil persons (family members), it is not adequate to use the ,soldiers' will” term as it directly indicates the status of the person whose last will is in question. Therefore, the „military will” term is more precise, bearing in mind that it implicates relation with military units. 
geographic position of Russia influenced the Russian legislator to include also a specific situation when the testator is in prospecting, Arctic or other similar expeditions. Exactly such legal solutions demonstrate that eternal link between law and life, that follow each other and spring up one from another.

The list of forms of wills qualifying for a notarial will represents numerus clausus in a double sense. First, the situations in which a testator may draw up such a will are itemised (e.g. he/she is in a stationary medical treatment institution or staying at penitentiary institutions). Second, persons who may attest a will are also itemised (e.g. chief physician, deputy chief physician, physician on duty, or the head of a hospital, or the head of a penitentiary institution).

In Serbian law, the testator may draw up a will aboard a vessel under the State Flag of the Republic of Serbia, before the captain of such a vessel. Soldiers' will may be drawn up by a testator on military duty, during mobilisation or war, before the squad commander or other commander of the same or a higher rank, or a commander of the military detachment. ${ }^{51}$

\subsection{The manner of drawing up wills qualifying as wills attested by a notary}

The authorised persons attest a will according to the rules for drawing up a notarial will, in compliance with art. 1124 and 1125 of the RFCC. ${ }^{52}$ At the same time, it means they are not authorised for attesting a closed will, as regulated with art. 1126 of the RFCC.

The testator is obliged to sign his/her will with his/her own hand with a witness in attendance who also signs the will. ${ }^{53}$ In legal literature, some opposed opinions are distinctive whether the mentioned provision represents a lex specialis in regard to the testator's possibilities to authorise another person to sign on his/her behalf, as opposed to the instructing provision to apply the rules for drawing up a notarial will. ${ }^{54}$ The attendance of one witness is a requirement for the validity of such a form of a will..$^{55}$

Following the attestation, the authorised person is obliged to forward, as soon as possible, the attested will to a notary in the place of abode of the testator. The

${ }^{51}$ See art. $108-109$ of the IA.

52 See art. 1127, para 2 subpara 2 of the RFCC.

${ }^{53}$ See art. 1127, para 2 subpara 1 of the RFCC.

${ }^{54}$ See: M. S. Abramenkov, P. V. Čugunov, 202.

55 The legislator is not explicit in regard to the attendance of a specified number of witnesses, but the relevant sources use singular in the part related to the obligation of witness attendance. See: Институт Государства и права Российской Академии Наук, 30; Институт Законодательства и Сравнительного правоведения при правительстве Российской Федерации, 58-59. The earlier explanations of limitations in regard to the witness qualification are also valid in this case. 
authorised person will forward the will to the competent notary via judicial bodies, or directly, if he/she knows the place of abode of the testator. ${ }^{56}$

In Serbian law, extraordinary forms of wills are drawn up according to the rules for drawing up a judicial will. ${ }^{57}$

\subsection{Legal nature of forms of wills qualifying as wills attested by a notary}

The issue of classification of such forms of wills in the classification of wills into regular, extraordinary and exceptional forms is interesting. Namely, such wills may only be drawn up by a person who is in specific, legally anticipated situations, in which most probably, as per the cautious thought of the legislator, he/she is not able to state his/her last will before a notary. Analysing such situations, we may conclude that the conditions related to the testator who is in stationary medical treatment, military or penitentiary institutions, aboard vessels and during expeditions. In legal literature we find that the wills of persons who are aboard a vessel or under military conditions, are classified as extraordinary forms of wills. ${ }^{58}$ Both in comparative and in Russian laws, such wills are drawn up according to the general rules for creating a regular form of a will. The characteristic circumstance is exactly that the will is drawn up in specific, extraordinary conditions; therefore, such wills are classified as extraordinary forms.

The extraordinary circumstance borne in mind by the Russian legislator on the occasion of regulating such forms of wills is the inaccessibility of a notary to the testator, who is in specific conditions of a limited freedom of movement. Thus, the Russian legislator authorises other persons to carry out the attestation of a will. Thereby, as per the letter of the law, if the testator, nonetheless, expresses his/her intention to invite a notary, and there is a reasonable possibility for satisfying such an intention, the authorised persons are obliged to undertake any measures necessary to invite a notary. ${ }^{59}$ The mentioned provision implies a subsidiarity of such form of a will in relation to a notarial will, being a regular form.

However, another characteristic of extraordinary forms of wills is their limited period of validity. ${ }^{60}$ It is tied to the flow of the legally stipulated period of time after the termination of extraordinary circumstances, which represented a justifiable condition for creating an extraordinary form of a will. In Serbian law, a will drawn

\footnotetext{
${ }^{56}$ See art. 1127, para 3 of the RFCC.

${ }^{57}$ See art. $108-109$ of the IA.

${ }^{58}$ See: J. Vidić, 1558, etc.

${ }^{59}$ See art. 1127 , para 4 the RFCC.

${ }^{60}$ The mentioned above is highlighted in Serbian legal literature. See: N. Stojanović, 207; J.
} Vidić, 1541-1544. 
up abroad a vessel becomes invalid with the passing of thirty days from the day of the testator's return to the Republic of Serbia; and a soldiers' will - with the passing of sixty days from the day the war ends, i.e. thirty days from the day of the testator's demobilisation. ${ }^{61}$

In Russian law, wills qualifying as wills attested by a notary are valid indefinitely. In that sense, such wills do not have all the characteristics that the extraordinary forms have. But any different classification of such wills is not justified - they are neither regular, nor exceptional forms. ${ }^{62} 63$

\section{A HANDWRITTEN WILL BEFORE WITNESSES}

A testator whose life is threatened due to some exceptional circumstances and who is deprived of an opportunity to create another form of a will, may express his/her own last will by writing and signing it in his/her own hand and in the presence of two witnesses. ${ }^{64}$ This is the only regulated private and exceptional form of a will in Russian law.

Legal nature of a writ does not depend on whether the writ contains the word „will". The legislator only prescribed the necessity that the content of a writ evidences that it is a will. ${ }^{65}$ According to the legislator's intention, two witnesses are obligatorily present at the creation of a will. ${ }^{66}$ The witnesses sign the will, confirming with their signature that they really attended the creation and that the will was signed by the testator. Although there are no explicit requirements in the law in regard to signing the will by the witnesses, it is only logical that the signature of a witness is a necessary evidence of his/her presence to the act of drawing up a will, which is a requirement for a valid creation of a will. ${ }^{67}$

${ }^{61}$ See art. $108-109$ of the IA.

${ }^{62}$ This is not about an exceptional form of a will, since it is drawn up according to the rules valid for a regular form of a will - for a notarial will.

${ }^{63}$ Concerning the issue of classification of a will form, one should be cautious when making a conclusion. The mentioned characteristics of extraordinary forms of wills, which are popularly accepted in Serbian legal literature, are not fully applicable in other European legal systems. The same remark is also made by J. Vidić, 1543.

${ }^{64}$ See art. 1129 the RFCC. Considering the mentioned conditions for a valid creation, such form of a will represents a mix of holograph and allograph forms of wills, which are widely spread in European legal systems. However, they are regular forms of wills in European legal systems. More about it, see: Jelena Vidić Trninić, Olografski i alografski testament u srpskom i uporednom pravu, Zbornik radova Pravnog fakulteta u Novom Sadu, 4/2016, 1251-1279.

${ }^{65}$ See art. 1129, para 1 subpara 2 the RFCC.

${ }^{66}$ The earlier explanations of limitations in regard to the witness qualification are also valid in this case.

${ }^{67}$ See: M. S. Abramenkov, P. V. Čugunov, 207-208. 
The term of exceptional circumstances is not defined by legislator. In legal literature, it is emphasised that natural disasters, war operations or similar circumstances are considered exceptional circumstances, when a person's life is threatened, and objectively he/she is deprived of an opportunity to create his/her will in due form (notarial or equivalent to it). ${ }^{68}$

At the request of stakeholders, before the expiry term set for acceptance of the inheritance, the court should confirm the fact that the character of the circumstances in which the will was drawn up were exceptional and justify the testamentary disposition in a simple written form. ${ }^{69}$ After the fact of the existence of exceptional circumstances has been confirmed by the court, the notary may initiate the probate procedure based on such a will. ${ }^{70}$

The will drawn up in such a way will only be valid for a month from the moment of the exceptional circumstances termination. After that, if the testator is still alive, the will loses legal force. ${ }^{71}$

Stipulating the obligation of confirming the fact of exceptional circumstances existence by the court and the time period for the validity of a will, the legislator endeavours to limit eventual abuses of testamentary dispositions in a simple written form. Whereby, with the provisions of a handwritten will before witnesses, an earlier created will in another form cannot be revoked, save for an earlier created handwritten will before witnesses. ${ }^{72}$

In Serbian law, its counterparts are a handwritten will and a written will before witnesses. However, these are regular forms of wills in Serbian law. A handwritten will must be written and signed by the testator in his/her own hand. A written will before witnesses is being drawn up by the testator by acknowledging an earlier written writ as his/her own and signing it with his/her own hand before two witnesses. ${ }^{73}$

${ }^{68}$ See: R. A. Kurbanov et al, 83; M. S. Abramenkov, P. V. Čugunov, 208. In Serbian legal literature, there is a dual observation of the term of exceptional circumstances - we differentiate exceptional circumstances in objective and subjective senses. Exceptional circumstances in objective sense are compelling events, which occurred suddenly or could not have been foreseen, and which affect a major or a minor group of people, in the manner that substantially impair their living situation (e.g.: war, fire, flood, mining accident, epidemic, and other natural or other disasters.) In subjective sense, exceptional circumstances are events affecting exclusively the testator's personality (e.g.: diseases, injuries, etc.) See: Oliver Antić, Usmeni testament u savremenom pravu, Anali Pravnog fakulteta u Beogradu, 5-6/1979, 509.

${ }^{69}$ See art. 1129, para 3 the RFCC. Stakeholders can be any persons designated as heirs in a will drawn up in such a way, but also any persons that would inherit the testator's estate if he had not drawn up such a will. See: Институт Государства и права Российской Академии Наук, 31.

${ }^{70}$ See: R. A. Kurbanov et al, 83.

${ }^{71}$ See art. 1129, para 2 of the RFCC.

${ }^{72}$ See: R. A. Kurbanov et al, 83.

${ }^{73}$ See art. $84-85$ of the IA. 


\section{AN INTERNATIONAL WILL}

The provisions on an international will are not integrated in the RF Civil Code, yet they are contained in the Convention providing a Uniform Law on the Form of an International Will. ${ }^{74}$ An international will, as a written, public and regular form of a will, represents an expression of unification of law, ${ }^{75}$ but it does not replace the existing forms of wills in the signatory states of the Convention. The testator is entitled to opt for whether he/she wants to create his/her will as international or in the form stipulated by domestic regulations.

In Serbian law the testator also has the mentioned right to an option.

\subsection{The manner of drawing up an international will}

The will must be drawn up in writing, on paper, and not on some other foundation. ${ }^{76}$ Whether a will is handwritten by the testator or any other person, or it is written using technical writing devices bears no significance. ${ }^{77}$

The testator submits the writ for attestation to a person authorised to draw up international wills. Every state specifies in a domestic law what persons will be authorised to draw up an international will, whereby the practice is that those are persons authorised for drawing up public forms of wills in domestic law. We conclude that in Russian law it can be a notary, a person whose attestation of wills according to Russian regulations qualifying with a will attested by a notary, an official of executive authorities of a local self-government unit in a place where there is no notary or an official of a consular mission of the Russian Federation.

The testator must state, before an authorised person and in the concurrent presence of two witnesses, that the writ is his/her own will and that he/she is familiar with its content. This statement must be given personally, orally and in Russian language by the testator. If he/she is not able to speak, he/she will give the statement through an interpreter. In the event that the testator is not in command of Russian,

${ }^{74}$ Contrary to it, in Serbian law, the provisions on international will are also conveyed in the Inheritance Act, for the sake of achieving transparency of all the forms of wills regulated under Serbian law. The Russian practice example has its advantage - the wording of the RF Civil Code is made less burdened.

75 The presence of the element of internationality is not a characteristic of international will. Namely, the name of will refers to the international character of regulations that set out the requirements for the validity of a will and to the international dimension of the validity of a will in the signatory states to the Convention. Whereby, the elements of internationality - either regarding the testator's or the heir's status, either regarding the property disposed of by the will - may, but does not have to, exist in the concrete case. More about it: Slavko Marković, Međunarodni testament, Zbornik radova Pravnog fakulteta u Nišu, 20/1980, 111.

${ }^{76}$ See: Ibid, 118.

${ }^{77}$ See art. 3 of the Uniform Law on the Form of an International Will, Annex to the Convention. 
he/she will give his/her statement through a translator, whereby the will itself can be in any language that the testator opts for. The testator does not have to reveal to the witnesses and the authorised person the content of the will itself. ${ }^{78}$

Having acknowledged the will, the testator is obliged to sign the will in the presence of the authorised person and two witnesses, that is to say to acknowledge the earlier signature as his/her own. In the event that the testator cannot sign himself (herself), he/she may, in compliance with the law, to authorise another person to do it on his/her behalf, which will be recorded on the writ and on the attestation of the international will by the authorised person for drawing up the will. ${ }^{79}$ Apart from signing at the end of the text of the will, the testator must sign each sheet of the will if there are more, whereby each sheet must be numbered.

Then, the will is signed by the witnesses and the authorised person, who will make a note on the will about the date of drawing up thereof. If there are no imperative provisions on safekeeping the will, the authorised person acts as the testator wishes. ${ }^{80}$ We conclude that, in Russian law, an international will must be given to the notary for safekeeping.

\subsection{The Certificate on the compliance of the will with the requirements of the form prescribed by the Convention}

Regarding the drawn up international will, the authorised person is obliged to issue a certificate on the compliance of the will with the requirements of the form prescribed by the Convention. The form of the certificate is provided in article 10 of the Annex to the Convention, whereby the national legislations may generate their own form, essentially complementing the certificate referred to in the Convention. The certificate contains data on the authorised person, testator and witnesses, date and place on drawing up the will, and on all the actions undertaken during the drawing up thereof.

The certificate represents a sufficient evidence on the formal validity of the writ as an international will, unless the opposite is proved. It only certifies that the requirements of the form referred to in the Convention are observed, whereby it itself cannot complement the irregularities of an international will. Also, the irregularities or even the absence of a certificate does not affect the validity of an international will. ${ }^{81}$

\footnotetext{
${ }^{78}$ See art. 4, para 1-2 of the Uniform Law on the Form of an International Will, Annex to the Convention.

${ }^{79}$ See art. 5 of the Uniform Law on the Form of an International Will, Annex to the Convention.

${ }^{80}$ See art. 6-7 of the Uniform Law on the Form of an International Will, Annex to the Convention.

${ }^{81}$ See art. $12-13$ of the Uniform Law on the Form of an International Will, Annex to the Convention. S. Marković, 123-124.
} 


\section{THE TESTAMENTARY DISPOSITION OF FUNDS IN BANKS}

A unique solution of Russian law, unknown to other legal systems, are special legal rules for a testamentary disposition of funds in the accounts in banks or other credit organisations. ${ }^{82}$ In Russian literature, these rules are not systematised as a special form of a will. ${ }^{83}$

The testator may declare his/her will how to dispose of his/her funds that he/she has in a bank ${ }^{84}$ in two ways. First, he/she may create some form of a will according to the procedure regulated by the provisions of art. 1124-1127 of the RFCC. Second, he/she can testamentary dispose by creating a writ in the branch of the bank where he/she holds an account ${ }^{85}$ The writ must be signed by the testator by his/her own hand, dated and attested by a bank official, who is authorised to accept the execution of the client's instructions concerning the funds in his/her account. ${ }^{86}$ Although there are special rules for their testamentary disposition, the rights to his/her funds in the accounts in a bank are incorporated in the estate and are inherited in compliance with the general rules, and are handed out to heirs under a certificate of right to inheritance. ${ }^{87}$

According to the letter of the law, the testamentary disposition of the funds in a bank account has the legal force of a notarial will. ${ }^{88}$ However, it is not a will, therefore the legislator does not name it as one.

${ }^{82}$ See art. 1128 of the RFCC. Until the Decision of the Government of the Russian Federation dated 01. 3. 2002 entered into force, the disposition of deposits in Sberbank of the Russian Federation and Centrobank of the Russian Federation and deposits with other commercial banks had fallen under two different regimes. In the former case, the deposits were not incorporated in the estate and the testator's creditors could not have been paid thereof. More about it, see: R. A. Kurbanov et al, 82-83; M. S. Abramenkov, P. V. Čugunov, 205-207; Институт Государства и права Российской Академии Наук, 31.

${ }^{83}$ See: Inna Leonidovna Korneeva, Nasledstvennoe pravo, Moskva 2019, 98-99; R. A. Kurbanov et al, 82; M. S. Abramenkov, P. V. Čugunov, 205.

84 The legal norm includes funds in all accounts in banks and other credit organisations, irrespective of the type and purpose of a concrete account. See: Institut Gosudarstva i prava Rossin̆skoŭ Akademii Nauk, 31.

${ }^{85}$ See art. 1128, para 1 of the RFCC. The execution of this legal norm was concretised with the passing of the Decision of the Russian Federation Government dated 27 May 2002, number 351 for the execution of regulations according to art. 1128, para 2 of the RFCC.

${ }^{86}$ See art. 1128 , para 2 of the RFCC.

${ }^{87}$ See art. 1128, para 3 of the RFCC. The attestation on the right to inheritance is issued by a notary, after the expiry of a six-month time period, observing the rule on a compulsory inheritance share and the portion of the spouse, who outlives the testator. See: M. S. Abramenkov, P. V. Čugunov, 205.

${ }^{88}$ See art. 1128, para 1 of the RFCC. 


\section{CONCLUDING CONSIDERATIONS}

There are similarities between the systems of forms of wills in Russian and Serbian laws, but also significant differences.

In Russian law, domination of public forms of wills and absence of oral forms of wills are noticeable. The only private form of a will is a handwritten will before witnesses, as an exceptional form of a will. As opposed to that, in Serbian law, the range of forms of wills offers a possibility of creating regular private forms of wills (a handwritten will and a written will before witnesses) and an oral will, as an exceptional form of a will.

Unlike Russian law, in Serbian law, a notarial will cannot be created by passing the writ to a notary. The justification of the Serbian legislator's restraint to regulate this form of creating wills, judicial and notarial, should be assessed from the aspect of the quality of a procedure of creating a will and the legal security.

An interesting solution of Russian testamentary law represents the regulation of a closed will, which is unknown in Serbian legal area. However, except the appeal of novelty, what elicits the attention to this form of a will is exactly this full realisation of the freedom of testamentary dispositions in relation to privacy of the content of a will, and again, it is a public form of a will, in the creation of which the representatives of public authorities take part. Although an international will as a public form of a will also provides the possibility of keeping the confidentiality of testamentary disposition, a closed will is characterised by the simpler rules for a valid drawing up form.

The specificity of the Russian inheritance-law norms is also the regulation of a group extraordinary form of a will, which comprises five sub-forms of wills qualifying as wills attested by a notary. These wills represent an example how the Russian legislator is attentive to the needs of a modern man, which is also a positive recommendation for the Serbian legislator. However, such wills are not limited in time, which is characteristic for extraordinary forms of wills in Serbian law. Extraordinary forms of will regulated both in Russian and in Serbian laws are soldiers' wills and wills drawn up aboard a vessel.

The special regulations for testamentary disposition of funds in a bank are also an authentic solution of the Russian legislator. There are no similar solutions in Serbian law.

Finally, we emphasise that the analysis of inheritance-law regulations of Russian law about the forms of wills, provides inspiring examples of possible changes of the solutions in Serbian law, which should be carefully considered, bearing in mind the procedure of the adoption of the Civil Code of the Republic of Serbia. The forms of wills of persons who are in stationary medical institutions or residing in eldercare and skilled nursing facilities, or staying at penitentiary institutions, are particularly interesting among the highlighted specificities of the 
Russian inheritance-law solutions. Also, condensation of a number of wills, having identical rules for drawing up, into a unique form of a will represents a positive example of nomotechnical economy, which is also possible to apply in Serbian law.

\section{REFERENCES}

Berger Adolf, Encyclopedic Dictionary of Roman Law, vol. 43, part 2, Philadelphia 1953. Абраменков Сергеевич Михаил, Чугунов Валерьевич Петр, Наследсйвенное ираво, Москва 2019.

Antić Oliver, „Usmeni testament u savremenom pravu“, Anali Pravnog fakulteta u Beogradu, 5-6/1979.

Arsenijević Bojana, „Tajno zaveštanje u pojedinim savremenim evropskim pravnim sistemima“, Zbornik Pravnog fakulteta u Nišu, 78/2018.

Vidić Jelena, „Vanredni oblici zaveštanja u pravu Srbije i ostalim savremenim pravima Evrope", Zbornik radova Pravnog fakulteta u Novom Sadu, 4/2017.

Civil Code of the Russian Federation, available at https://www.zakonrf.info/gk.

Act on Non-Contentious Proceedings (Zakon o vanparničnom postupku, Službeni glasnik SRS, br. 25/82 i 48/88 i Službeni glasnik RS, br. 46/95 - dr. zakon, 18/2005 - dr. zakon, 85/2012, 45/2013 - dr. zakon, 55/2014, 6/2015 i 106/2015 - dr. zakon).

Inheritance Act (Zakon o nasleđivanju, Službeni glasnik RS, br. 46/95, 101/2003 odluka USRS i 6/2015.).

Институт Государства и права Российской Академии Наук, Комментарий к Гражданскому Кодексу Российской Федераичи, Части Третьей, Москва 2004.

Институт Законодательства и Сравнительного правоведения при правительстве Российской Федерации, Комментарий к Гражданскому Кодексу Российской Федерации, Части Третьей (Постатейный), Второе Издание, Москва 2007.

Italian Code Civil, available at https://www.altalex.com/documents/codici-altalex/2015/ 01/02/codice-civile.

Convention providing a Uniform Law on the Form of an International Will, available at http://www.unidroit.org/instruments/succession.

Корнеева Леонидовна Инна, Наследстивенное ирраво, Москва 2019.

Курбанов Афатович Рашад et al, Наследсиивенное йраво, Москва 2018.

Лотарева Борисовна Юлия, „Свобода завещания и случаи ее ограничения“, Вестник Российског̃о университета дружбы народов, Серия: Юридические науки, 4/2010.

Marković Slavko, „Međunarodni testament“, Zbornik radova Pravnog fakulteta $u$ Nišu, 20/1980.

Stojanović Nataša, Nasledno pravo, Niš 2011.

Trninić Vidić Jelena, „Olografski i alografski testament u srpskom i uporednom pravu“, Zbornik radova Pravnog fakulteta u Novom Sadu, 4/2016.

French Code Civil, available at https://www.legifrance.gouv.fr/affichCode.do?cidTexte= LEGITEXT000006070721. 
Bojana O. Arsenijević, student doktorskih studija

Univerzitet $u$ Nišu

Pravni fakultet u Nišu

bojana.arsa@yahoo.com

\section{Oblici zaveštanja u savremenom ruskom pravu, sa posebnim osvrtom na srpsko pravo}

Sažetak: U radu autorka analizira oblike zaveštanja u ruskom pravu i uslove njihove pravne punovažnosti. U ruskom pravu primetna je dominacija javnih oblika zaveštanja. Tako, regulisani su javnobeležničko zaveštanje, zaveštanje izjednačeno sa javnobeležničkim zaveštanjem i tajno zaveštanje. Imajući u vidu da je Ruska Federacija ratifikovala Konvenciju o jednoobraznom zakonu o obliku međunarodnog zaveštanja, u ruskom pravu regulisano je i međunarodno zaveštanje. Vodeći računa o izuzetnim okolnostima, ruski zakonodavac je regulisao svojeručno zaveštanje pred svedocima, koje predstavlja i jedini privatni oblik zaveštanja. Posebna pravna pravila važe za zaveštajno raspolaganje novčanim sredstvima na računima kod banaka i drugih kreditnih organizacija. Analizirajući naslednopravna pravila u ruskom pravu, omogućava se uočavanje sličnosti $i$ razlika u odnosu na odgovarajuće naslednopravne propise drugih evropskih država, u prvom redu Republike Srbije. važnosti.

Ključne reči: rusko pravo, srpsko pravo, oblici zaveštanja, uslovi puno-

Datum prijema rada: 10.09.2019. 